\title{
Community acquired Acinetobacter baumannii in pediatric patients under 1 year old with a clinical diagnosis of whooping cough in Lima, Peru
}

\author{
Isaac Peña-Tuesta ${ }^{1,2+}$, Cristina del Valle-Vargas ${ }^{3 \dagger}$, Veronica Petrozzi-Helasvuo ${ }^{1}$, Miguel Angel Aguilar-Luis ${ }^{1,2}$,
} Hugo Carrillo-Ng ${ }^{1,2}$, Wilmer Silva-Caso ${ }^{1,2}$ and Juana del Valle-Mendoza ${ }^{1,2^{*}}$ (1)

\begin{abstract}
Objective: This study aimed to determine the prevalence of $A$. baumannii in children aged less than 1 year admitted with a clinical diagnosis of whooping cough.

Results: A total of 225 nasopharyngeal samples from children under 1 year old hospitalized with clinical diagnosis of whooping cough were studied from January 2010 to July 2012. The presence of A. baumannii was detected in 20.89\% (47/225) of the nasopharyngeal swab samples. Among the 47 patients with A. baumannii: 5 were diagnosed with $A$. baumannii monoinfection, 17 co-infection with bacteria, 7 co-infection with virus and 18 co-infection with bacteria + virus. It was observed that $51.6 \%$ (116/225) were children between 29 days and 3 months old, this same group had the highest overall prevalence with 53.3\%. The most common co-infecting pathogens were Bordetella pertussis in $55.3 \%$, Adenovirus in $42.6 \%$ and Mycoplasma pneumoniae in $23.4 \%$.
\end{abstract}

Keywords: A. baumannii, Acute respiratory infections, ARI, Bordetella pertussis, Peru

\section{Introduction}

Acinetobacter is an opportunistic gram-negative coccobacilli bacterial family associated with a wide variety of hospital-acquired infections, often transmitted to patients via persistence on environmental surfaces and transient colonization of the hands of health care workers [1-3]. Acinetobacter baumannii is the most virulent of all Acinetobacter species, being nosocomial pneumonia its most common and lethal clinical presentation [4, 5]. The widespread resistance of these bacteria against a

\footnotetext{
*Correspondence: juana.delvalle@upc.pe; joana.del.valle@gmail.com ${ }^{\dagger}$ Isaac Peña-Tuesta and Cristina del Valle-Vargas contributed equally to this article

1 School of Medicine, Research Center of the Faculty of Health Sciences, Universidad Peruana de Ciencias Aplicadas, Lima, Peru

Full list of author information is available at the end of the article
}

variety of antibiotics has become a major threat for public health [1]. The main predisposing factors for infection are colonization pressure, selection by exposure to broad-spectrum antibiotics and disruption of anatomical barriers. Consequently, immunocompromised patients are the most vulnerable, with higher incidence of infection occurring in intensive care units (UCIs), long-term hospitalized patients or patients undergoing major invasive procedures [5]

In Peru, acute respiratory infections (ARIs) continue to be the leading cause of premature mortality. For example, in the year 2019 a total of 2,501,436 cases of acute respiratory infections were registered in children under 5 years old, being the ones younger than 1 year old the most commonly affected [6]. A great variety of pathogens have been detected in children with ARI in Peru. For example a previous study reported that the most common viruses 
in children with ARI were RSV-A, followed by influenza A, Parainfluenza-1 and 2 [7]. Also, other studies have reported a high prevalence of atypical bacteria such as Mycoplasma Pneumonia, Chlamydia pneumoniae and Bordetella pertussis in pediatric patients with ARI $[8,9]$. Among acute respiratory infections, whooping cough remains a large cause of morbidity and mortality in Peru. In a previous study [10], B. pertussis was detected in $39.54 \%$ children with whooping cough, being more frequent in those younger than 3 months old. However, many children did not have a etiological diagnosis and other respiratory pathogens may be involved. Data on the epidemiology of $A$. baumannii and its role in respiratory infections among pediatric patients in Peru is still scarce. Therefore, the aim of this study is to determine the prevalence of $A$. baumannii in children aged less than 1 year old hospitalized for whooping cough.

\section{Main text}

\section{Materials and methods}

\section{Patients and study design}

The current study was conducted as part of a previous study evaluating the epidemiology of respiratory pathogens in children younger than 1 year old hospitalized with whooping cough [10]. In brief, a prospective cross-sectional study was conducted in five hospitals in Lima, Peru from January 2010 to July 2012. The study regions had a representative population, since Lima and Cajamarca have high rates ARIs cases.

\section{Samples}

225 samples of children younger than 1 year old were included for analysis. For this analysis, the remnants of the respiratory samples obtained from a previous study [10]. We could only analyze 225/392 samples due to insufficient or inadequate state of the conservation of the remaining isolates.

\section{Ethics statement}

This study was approved by the Research Ethics Board of the Hospital Docente Regional de Cajamarca, Peru. Samples were collected after a parent or guardian signed the informed consent to agree to participate, the informed consent was taken as a part of a previous study [10], which allowed the use of the samples for future studies. All procedures were performed under the international ethics guidelines for research in human healthcare by the Council for International Organizations of Medical Sciences (CIOMS) and the World Health Organization (WHO).

\section{DNA extraction}

DNA was extracted from a volume of $200 \mu \mathrm{L}$ of each sample using a commercial kit (High Pure Template Preparation Kit; Roche Applied Science, Germany) according to the manufacturer's instructions.

\section{PCR amplification}

The presence of A. baumannii was determined using a real-time PCR assay for the gen OXA-51, an independent region of the $A$. baumannii genome describe by Chen et al. [11] (Additional file 1: Table S1).

The product LightCycler FastStart DNA Master HybProbe (Roche Applied Science, Germany) was used to prepare the reaction mixture which contained $10.6 \mu \mathrm{L}$ of free DNAsa/RNAsa's water, $2.4 \mu \mathrm{L}$ of $\mathrm{Mg}^{+2}$ solution in a concentration of $25 \mathrm{mM}, 2.0 \mu \mathrm{L}$ of the Faststart enzyme, $1 \mu \mathrm{L}$ of each specific primer for OXA-51 in a $1 \mathrm{mM}$ concentration, $1 \mu \mathrm{L}$ of the specific quencher and $2 \mu \mathrm{L}$ DNA. The amplifications conditions were $95^{\circ} \mathrm{C}$ for $10 \mathrm{~min}$ followed by 55 cycles of $95^{\circ} \mathrm{C}$ for $5 \mathrm{~s}, 60^{\circ} \mathrm{C}$ for $5 \mathrm{~s}$ and $72{ }^{\circ} \mathrm{C}$ for $15 \mathrm{~s}$. All procedures were performed in a LightCycler 2.0 instrument and data were analyzed with LightCycler software 4.1 (Roche Diagnostics, Mannheim, Germany).

\section{Statistical analysis}

Qualitative variables were reported as frequencies and percentages. All analyses and graphs were carried out using the GraphPad 9.1.0 software (San Diego, CA, USA).

\section{Results}

A total of 225 nasopharyngeal samples from children under 1 year old hospitalized with clinical diagnosis of whooping cough were studied from January 2010 to July 2012. The presence of $A$. baumannii was detected in $20.89 \%(47 / 225)$ of the nasopharyngeal swab samples by the Real Time PCR of the OXA-51 gene. Additional file 2: Fig. S1 shows the distribution of infection pattern among the patients with $A$. baumannii diagnosis. Additional file 2: Fig. S1A shows that among the 47 patients with $A$. baumannii: 5 were diagnosed with $A$. baumannii monoinfection, 17 co-infection with bacteria, 7 co-infection with virus and 18 co-infection with bacteria + virus. In the case of co-infections patients were diagnosed with up to six pathogens at the same time, as shown in Additional file 2: Fig. S1B.

Table 1 shows the demographic characteristics of our study population. It was observed that $51.6 \%(116 / 225)$ were children between 29 days and 3 months old, this same group had the highest overall prevalence with $53.3 \%$. No significant difference in gender was observed in the distribution of our studied population nor in the prevalence of positive cases of $A$. baumannii. Moreover, 
Table 1 Prevalence and demographic characteristics of the the patients studied

\begin{tabular}{|c|c|c|c|c|c|c|}
\hline \multirow[t]{2}{*}{ Characteristics } & \multicolumn{2}{|c|}{ Total patients } & \multicolumn{2}{|c|}{ Patients positive for $A$. baumannii } & \multicolumn{2}{|c|}{$\begin{array}{l}\text { Patients negative for } A \text {. } \\
\text { baumannii }\end{array}$} \\
\hline & $\begin{array}{l}\text { Frequency } \\
n=225(\%)\end{array}$ & $\begin{array}{l}\text { Prevalence } \\
(\%)\end{array}$ & $\begin{array}{l}\text { Frequency } \\
(n=47)\end{array}$ & $\begin{array}{l}\text { Prevalence } \\
(\%)\end{array}$ & $\begin{array}{l}\text { Frequency } \\
(n=178)\end{array}$ & $\begin{array}{l}\text { Prevalence } \\
(\%)\end{array}$ \\
\hline \multicolumn{7}{|l|}{ Age } \\
\hline$\leq 28$ days & 14 & 6.2 & 3 & 6.4 & 12 & 6.7 \\
\hline 29 days $-<3$ months & 116 & 51.6 & 25 & 53.3 & 91 & 51.1 \\
\hline $3-<6$ months & 63 & 28.00 & 12 & 25.4 & 50 & 28.1 \\
\hline 6-12 months & 32 & 14.2 & 7 & 14.9 & 25 & 14.1 \\
\hline \multicolumn{7}{|l|}{ Sex distribution } \\
\hline Male & 119 & 52.8 & 25 & 53.2 & 94 & 52.8 \\
\hline Female & 106 & 47.2 & 22 & 46.8 & 84 & 47.2 \\
\hline \multicolumn{7}{|l|}{ Patient setting } \\
\hline Inpatient & 202 & 89.78 & 43 & 91.49 & 159 & 89.33 \\
\hline $\mathrm{ICU}$ & 23 & 10.22 & 4 & 8.51 & 19 & 10.67 \\
\hline \multicolumn{7}{|l|}{ Nutritional status } \\
\hline Malnutrition & 13 & 5.8 & 2 & 4.3 & 11 & 6.2 \\
\hline Obesity & 3 & 1.3 & 1 & 2.1 & 2 & 1.1 \\
\hline \multicolumn{7}{|l|}{ Household contacts } \\
\hline Mother & 46 & 20.4 & 14 & 29.8 & 32 & 17.9 \\
\hline Father & 16 & 7.1 & 4 & 8.5 & 12 & 6.7 \\
\hline Siblings $\leq 10$ years old & 55 & 24.4 & 7 & 14.9 & 48 & 26.9 \\
\hline Siblings $\geq 10$ years old & 6 & 2.7 & 2 & 4.3 & 4 & 2.2 \\
\hline Uncles/Aunts & 26 & 11.6 & 10 & 21.3 & 16 & 8.9 \\
\hline Others & 3 & 1.3 & 1 & 2.1 & 2 & 1.1 \\
\hline
\end{tabular}

the evaluation of household contacts was also performed. Most of the patients had contact with their respective mother (20.4\%) and siblings younger than 10 years old (24.4\%). In the case of patients positive for A. baumannii the proportion of patients that had contact with an ill mother was (29.8\%) compared to patients without $A$. baumannii (17.9\%).

Table 2 shows the most frequent clinical signs and symptoms, as well as the clinical outcomes in patients according to their infection status. The clinical manifestations between the groups with infection by $A$. baumannii as the only identified microorganism and $A$. baumannii in coinfection with other bacteria or viruses do not show many differences. A low frequency of fever is observed in the $A$. baumannii + virus group. Difficulty breastfeeding and cough paroxysms occurred in all infants with $A$. baumannii monoinfection and all those coinfected with $A$. baumannii virus presented respiratory distress. Patients that were admitted to ICU were 1 in the A. Bauman$n i i+$ bacteria group, 1 in the $A$. Baumannii + virus and 2 in the $A$. Baumannii + bacteria + virus group. Mortality occurred in 2 cases of $A$. Baumannii + bacteria + virus and in 1 case of $A$. Baumannii + bacteria.
Finally, an evaluation of the bacterial and viral coinfections was performed, as shown in Table 3. It was observed that in only $10.6 \%(5 / 47)$ of the patients $A$. baumannii was the detected as a single pathogen. The groups with the higher proportion of patients was the one with two infectious agents (A. baumannii + bacteria) with $25.5 \%$ and the ones with three infectious agents (A. baumannii + bacteria + virus) with $27.5 \%$. We could highlight that $26 / 47$ (55.3\%) of pediatric patients with whooping cough were diagnosed with $A$. baumannii in addition to B. pertussis. Followed by Mycoplasma pneumoniae coinfection in $11 / 47$ cases $(23.4 \%)$. In the case of viral pathogens, the most frequently co-detected was adenovirus with $20 / 47$ (42.6\%).

\section{Discussion}

Interest in Acinetobacter baumannii has been growing for the past years due to the emergence of multiresistant strains, that affect particularly adult patients with prolonged hospital stays and major procedures [12]. However, in hot and humid areas, such as tropical countries, infections by this pathogen can be community-acquired $[12,13]$. 


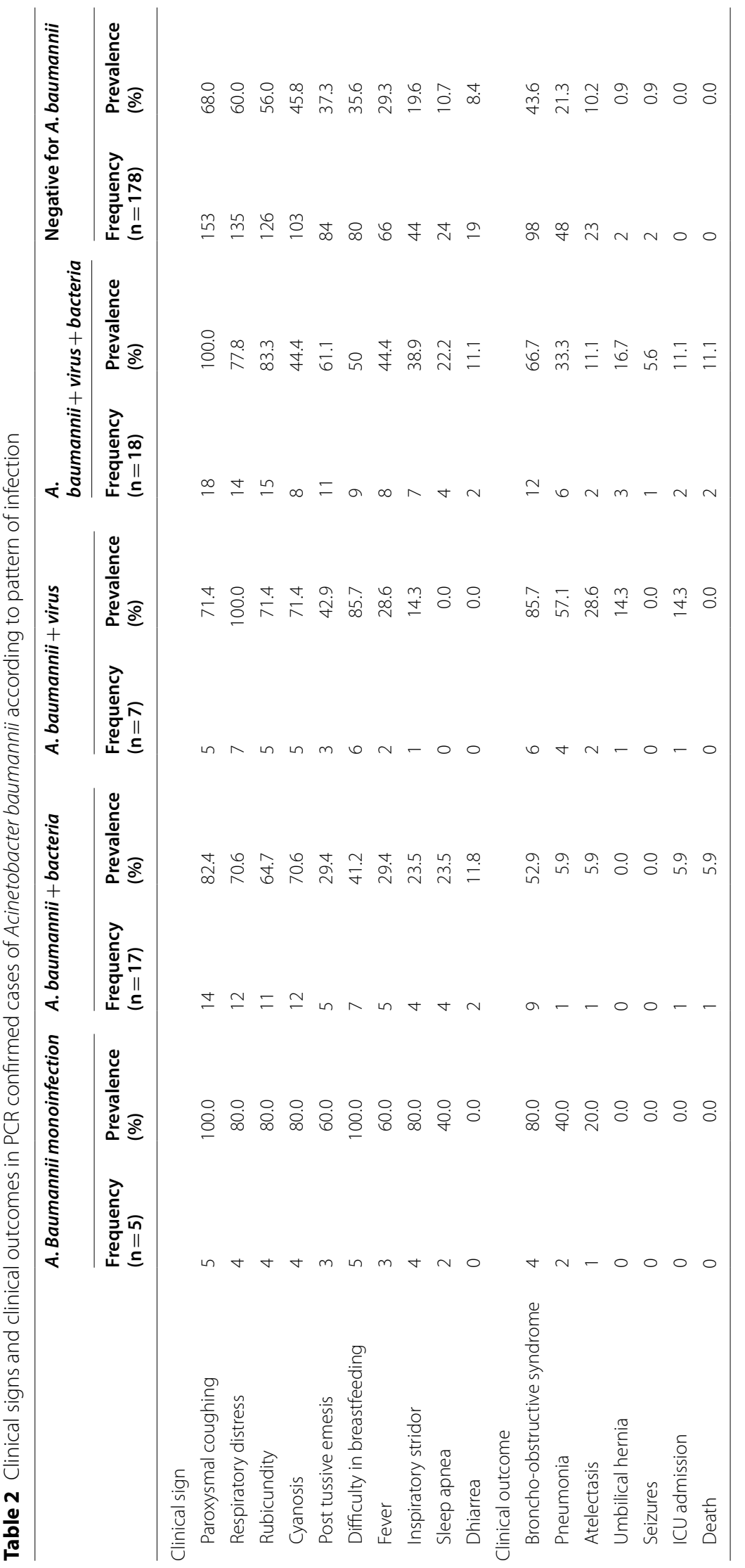


Table 3 Bacterial and viral co-detection in positive children with A. baumannii with a clinical diagnosis of whooping cough

\begin{tabular}{|c|c|c|c|c|c|}
\hline \multicolumn{3}{|l|}{ Etiologic agents } & \multirow{2}{*}{$\begin{array}{l}\mathrm{N} \\
(47)\end{array}$} & \multirow[t]{2}{*}{$\%$} & \multirow{2}{*}{$\begin{array}{l}\text { Total } \\
\%\end{array}$} \\
\hline Number & Type & Species & & & \\
\hline One-infectious agent & Bacterial & A. baumannii & 5 & 10.6 & 10.6 \\
\hline \multirow[t]{6}{*}{ Two-infectious agents } & Bacterial & A. baumannii $+M$. pneumoniae & 4 & 8.5 & \\
\hline & & A. Baumannii + B. pertussis & 8 & 17 & 25.5 \\
\hline & Bacterial-Viral & A. baumannii + ADV & 2 & 4.3 & 10.6 \\
\hline & & A. baumannii + Flu-B & 1 & 2.1 & \\
\hline & & A. baumannii + PIV-1 & 1 & 2.1 & \\
\hline & & A. baumannii + PIV-3 & 1 & 2.1 & \\
\hline \multirow[t]{9}{*}{ Three-infectious agents } & Bacterial & A. baumannii + C. pneumoniae + M. pneumoniae & 1 & 2.1 & 8.5 \\
\hline & & A. baumannii + C. pneumoniae + B. pertussis & 1 & 2.1 & \\
\hline & & A. baumannii $+M$. pneumoniae $+B$. pertussis & 2 & 4.3 & \\
\hline & Bacterial-Viral & A. baumannii + C. pneumoniae + RSV-A & 1 & 2.1 & 27.5 \\
\hline & & A. baumannii + M. pneumoniae + ADV & 1 & 2.1 & \\
\hline & & A. baumannii + B. pertussis + ADV & 8 & 17 & \\
\hline & & A. baumannii + B. pertussis + Flu-B & 1 & 2.1 & \\
\hline & & A. baumannii + ADV + Flu-B & 1 & 2.1 & \\
\hline & & A. baumannii + ADV + Flu-A & 1 & 2.1 & \\
\hline \multirow[t]{4}{*}{ Four-infectious agents } & Bacterial & A. baumannii + C. pneumoniae $+M$. pneumoniae $+B$. pertussis & 1 & 2.1 & 2.1 \\
\hline & Bacterial-Viral & A. baumannii + C. pneumoniae + ADV + RSV-A & 1 & 2.1 & 8.5 \\
\hline & & A. baumannii + B. pertussis + ADV + Flu-B & 2 & 4.3 & \\
\hline & & A. baumannii + M. pneumoniae + ADV + Flu-B & 1 & 2.1 & \\
\hline \multirow[t]{2}{*}{ Five-infectious agents } & Bacterial-Viral & A. baumannii + C. pneumoniae + B. pertussis + ADV + Flu-B & 1 & 2.1 & 4.2 \\
\hline & & A. baumannii + B. pertussis + ADV + Flu-A + Flu-B & 1 & 2.1 & \\
\hline Six-infectious agents & Bacterial-Viral & A. baumannii + C. pneumoniae + M. pneumoniae + B. pertussis $+A D V+$ Flu-B & 1 & 2.1 & 2.1 \\
\hline
\end{tabular}

Currently, the epidemiology of $A$. baumannii in pediatric patients have been a topic of great interest due to the increasing rates of infection and antibiotic resistance [14]. Infection by this pathogen predominantly affect pediatric patients, causing detrimental outcomes on their health, such as prolonged ICU stays and death $[15,16]$. Previous studies show that this pathogen infects pediatric critically ill patients, with underlying diseases, immune deficiency, and invasive operations [15]. Also, outbreaks have been reported in neonatal and pediatric intensive care units, as well as burn units [16]. This pathogen has been also been associated to lower respiratory tract infection in pediatric patients with tracheostomy [17]. This pathogen causes serious disease due to the presence of several virulence factors, including porins, lipopolysaccharides, capsular proteins, among others. These have been associated with adherence and invasion properties of this bacteria, biofilm formation and evasion of the host immune response [18]. On the other hand, its ability to develop multiple antibiotic resistance mechanisms have rendered most antibiotics useless. The expression of metallo beta-lactamases, carbapenemases and efflux pumps contribute to the resistance towards the most important antibiotics in the treatment of this bacteria $[19,20]$.
The epidemiology of this pathogen has not been extensively studied in children with non-serious illness outside of intensive care units. Therefore, we performed the first study evaluating the presence of Acinetobacter baumannii in pediatric patients under 1 year old with a clinical syndrome of whooping cough. The current study was carried out as part of a previously published report [10], in which the presence of Bordetella pertussis was detected in 155/392 (39.54\%) children under 1 year old with whooping cough; nonetheless, more than half of the patients remain undiagnosed. Of the total 392 samples collected previously, we could only analyze 225 due to insufficient or inadequate state of conservation of the remaining 167 isolates. We report a prevalence of $20.89 \%$ of $A$. baumannii, which corresponds to 47 cases of the total 225 nasopharyngeal samples used for this study. The age group with the greater number of cases were young infant between 29 days to $<3$ months, followed by the 3 months $-<6$ months, these findings highlight the need to maintain a high clinical suspicion particularly in this age groups. We suspect that most of the patients were colonized by community-acquired $A$. baumannii, given that samples were taken upon admission to hospitalization. The presence of $A$. baumannii in relation to 
whooping cough have also been reported previously, for example, it has been detected in children with whooping cough as a complication, causing severe pertussis and pneumonia [21]. However, this is the first report of this pathogen in young pediatric patients with communityacquired $A$. baumannii.

In the present study we found that $A$. baumannii infection may be detected in addition to other respiratory viral and bacterial pathogens, with up to six infectious agents in the same patient. We found that $A$. baumannii monoinfection was only detected in 5 patients. The most frequent co-detected pathogens were Bordetella pertussis, Mycoplasma pneumoniae and Adenovirus. The nasopharynx of pediatric patients can harbour a great variety of different viruses and bacterial species. Under different circumstances of health and disease, a certain microorganism may be pathogenic and others only colonizers $[22,23]$. In the current study the majority of patients had co-detection of at least two infectious agents; however, not all of them necessarily contribute to the development of disease and some may be only colonizers. We could highlight the high frequency of co-detection between $B$. pertussis and A. baumannii, which was detected in $55.3 \%$ of the total samples analyzed. The co-infection between these pathogens has not been reported previously, also the presence of $A$. baumannii was higher than expected in nasopharyngeal samples from patients with whooping cough and may have a role in the pathogenesis of this disease.

Finally, we performed an analysis of the clinical symptoms and outcomes between the groups with different patterns of infection, to determine if co-infections contribute to distinct clinical features. Clinical symptoms were similar between the different patterns of infections; however, clinical outcomes such as broncho-obstructive syndrome, pneumonia, death and ICU admission, were more frequent in the groups of A. baumannii with coinfections compared to patients without $A$. baumannii. These findings may indicate that co-infections between A. baumannii and other respiratory pathogens may lead to worse outcomes. Similarly, a previous review of viral bacterial co-infection of the respiratory tract demonstrates that co-infections are associated with detrimental effects on the patients such as higher risk to develop more severe disease [22].

In conclusion, this is the first report describing the presence of community-acquired A. baumannii in nasopharyngeal samples of children under 1 year old with whooping cough. Co-detection with multiple pathogens is frequent, with up to 6 respiratory infectious agents at the same time, being A. baumannii and B. pertussis coinfection the most prevalent. Further studies are required to determine the role of Acinetobacter baumannii infections in acute respiratory infections in young children, particularly in children with non-critical disease and outside of intensive care units.

\section{Limitations}

Firstly, an important limitation is that resistance to $A$. baumannii was not evaluated. Also, general and specific genotype distribution of $A$. baumannii varies mong geographic areas, therefore, it is important to carry out surveillance studies of this pathogen and clonality.

\section{Abbreviations}

ARIs: Acute respiratory infections; UCls: Intensive care units; PCR: Polymerase chain reaction; DNA: Deoxyribonucleic acid; bp: Base pairs.

\section{Supplementary Information}

The online version contains supplementary material available at https://doi. org/10.1186/s13104-021-05826-y.

Additional file 1: Table S1. Primers and probe for the detection of the OXA-51 gene of Acinetobacter baumannii.

Additional file 2: Fig. S1. A: Pattern of infection in the total population. B: Co-detection of pathogens in Acinetobacter baumannii positive children.

\section{Acknowledgements}

We thank the staff of the health network from Peru.

\section{Authors' contributions}

JdVM, WSC and MAAL designed the study protocol. IPT, MAAL and JdVM performed the PCR. JdVM, VPH, CdV, HCN and WSC were responsible for obtaining funding and laboratory work supervision. JdVM, VPH, CdVV, HCN and WSC were responsible for the clinical assessment, samples collection and database completion. JdVM, CdV, HCN, were responsible to draft the manuscript. All authors critically revised the manuscript for intellectual content. All authors read and approved the final manuscript.

Funding

This work was supported by Dirección de Investigación, Universidad Peruana de Ciencias Aplicadas, Grant No A-072-2020-UPC, Lima-Peru.

Availability of data and materials

Abstraction format used in the study and dataset are available and accessible from the corresponding author upon request in the link: https://figshare. com/s/6990881fe600d0a27881

\section{Declarations}

Ethics approval and consent to participate

This study was approved by the Research Ethics Board of the Hospital Docente Regional de Cajamarca, Peru. The samples were obtained as part of the public health surveillance system for which they were dispensed with informed consent according to the Ethical Guidelines of the World Health Organization.

\section{Consent for publication \\ Not applicable.}

\section{Competing interests}

On behalf of all authors, the corresponding author states that there are no conflicts of interest or funding related to this study. 


\section{Author details}

'School of Medicine, Research Center of the Faculty of Health Sciences, Universidad Peruana de Ciencias Aplicadas, Lima, Peru. ${ }^{2}$ Laboratorio de Biologia Molecular, Instituto de Investigación Nutricional, Lima, Peru. ${ }^{3}$ Department of Medicine, School of Medicine, Universidad de Barcelona, Barcelona, Spain.

Received: 23 July 2021 Accepted: 26 October 2021

Published online: 10 November 2021

\section{References}

1. Bergogne-Bérézin E, Tower KJ. Acinetobacter spp. as nosocomial pathogens: microbiological, clinical, and epidemiological features. Clin Microbiol Rev. 1996;9(2):148-65.

2. McDonald LC, Banerjee SN, Jarvis WR. Seasonal variation of Acinetobacter infections: 1987-1996. Nosocomial infections surveillance system. Clin Infect Dis. 1999:29(5):1133-7.

3. Spellberg B, Bonomo RA. "Airborne assault": a new dimension in Acinetobacter baumannii transmission. Crit Care Med. 2013:41(8):2042-4.

4. Chusri S, Chongsuvivatwong V, Rivera Jl, Silpapojakul K, Singkhamanan K, McNeil E, Doi Y. Clinical outcomes of hospital-acquired infection with Acinetobacter nosocomialis and Acinetobacter pittii. Antimicrob Agents Chemother. 2014:58(7):4172-9.

5. Wong D, Nielsen TB, Bonomo RA, Pantapalangkoor P, Luna B, Spellberg B. Clinical and pathophysiological overview of acinetobacter infections: a century of challenges. Clin Microbiol Rev. 2017;30(1):409-47.

6. Ministerio de Salud. Situación de salud de IRAS. 2020;24. http://www.dge. gob.pe/portal/docs/vigilancia/sala/2018/SE33/iras.pdf. Accessed 8 May 2021

7. del Valle MJ, Cornejo-Tapia A, Weilg P, Verne E, Nazario-Fuertes R, Ugarte $C$, del Valle LJ, Pumarola T. Incidence of respiratory viruses in Peruvian children with acute respiratory infections. J Med Virol. 2015:87(6):917-24.

8. Del Valle-Mendoza J, Orellana-Peralta F, Marcelo-Rodríguez A, Verne E, Esquivel-Vizcarra M, Silva-Caso W, Aguilar-Luis MA, Weilg P, Casabona-Oré V, Ugarte C, Del Valle LJ. High prevalence of Mycoplasma pneumoniae and Chlamydia pneumoniae in children with acute respiratory infections from Lima, Peru. PLoS ONE. 2017;12(1):e0170787.

9. Pavic-Espinoza I, Bendezú-Medina S, Herrera-Alzamora A, et al. High prevalence of Bordetella pertussis in children under 5 years old hospitalized with acute respiratory infections in Lima, Peru. BMC Infect Dis. 2015:15:554 (Published 2015 Dec 2).

10. Castillo ME, Bada C, Del Aguila O, Petrozzi-Helasvuo V, Casabona-Ore V, Reyes I, Del Valle-Mendoza J. Detection of Bordetella pertussis using a PCR test in infants younger than one year old hospitalized with whooping cough in five Peruvian hospitals. Int J Infect Dis. 2015;41:36-41.
11. Chen TL, Lee YT, Kuo SC, Hsueh PR, Chang FY, Siu LK, Ko WC, Fung CP. Emergence and distribution of plasmids bearing the blaOXA-51-like gene with an upstream ISAba1 in carbapenem-resistant Acinetobacter baumannii isolates in Taiwan. Antimicrob Agents Chemother. 2010;54(11):4575-81.

12. Joly-Guillou ML. Clinical impact and pathogenicity of Acinetobacter. Clin Microbiol Infect. 2005:11(11):868-73.

13. Houang ETS, Chu YW, Leung CM, et al. Epidemiology and infection control implications of Acinetobacter spp. in Hong Kong. J Clin Microbiol. 2001;39:228-34.

14. Logan LK, Gandra S, Trett A, Weinstein RA, Laxminarayan R. Acinetobacter baumannii resistance trends in children in the United States, 1999-2012. J Pediatric Infect Dis Soc. 2019;8(2):136-42.

15. Hu J, Robinson JL. Systematic review of invasive Acinetobacter infections in children. Can J Infect Dis Med Microbiol. 2010;21(2):83-8.

16. Shi J, Sun T, Cui Y, Wang C, Wang F, Zhou Y, Miao H, Shan Y, Zhang Y. Multidrug resistant and extensively drug resistant Acinetobacter baumannii hospital infection associated with high mortality: a retrospective study in the pediatric intensive care unit. BMC Infect Dis. 2020;20(1):597.

17. Grosse-Onnebrink J, Rudloff J, Kessler C, Werner C, Dougherty GW, Kerschke L, Kahl BC, Omran H. Acinetobacter baumannii is a risk factor for lower respiratory tract infections in children and adolescents with a tracheostomy. Pediatr Infect Dis J. 2019;38(10):1005-9.

18. Lee CR, Lee JH, Park M, et al. Biology of Acinetobacter baumannii: pathogenesis, antibiotic resistance mechanisms, and prospective treatment options. Front Cell Infect Microbiol. 2017;7:55.

19. Behzadi P, García-Perdomo HA, Karpiński TM, Issakhanian L. Metallo-ßlactamases: a review. Mol Biol Rep. 2020;47(8):6281-94.

20. Donadu MG, Zanetti S, Nagy Ádám L, Barrak I, Gajdács M. Insights on carbapenem-resistant Acinetobacter baumannii: phenotypic characterization of relevant isolates. Acta Biol Szeged. 2021;65(1):85-2.

21. Wang C, Zhang H, Zhang Y, Xu L, Miao M, Yang H, Liu Y, He S, Pang L. Analysis of clinical characteristics of severe pertussis in infants and children: a retrospective study. BMC Pediatr. 2021;21(1):65.

22. Brealey JC, Sly PD, Young PR, Chappell KJ. Viral bacterial co-infection of the respiratory tract during early childhood. FEMS Microbiol Lett. 2015;362(10):fnv062.

23. Adegbola RA, DeAntonio R, Hill PC, Roca A, Usuf E, Hoet B, Greenwood BM. Carriage of Streptococcus pneumoniae and other respiratory bacterial pathogens in low and lower-middle income countries: a systematic review and meta-analysis. PLoS ONE. 2014;9(8):e103293.

\section{Publisher's Note}

Springer Nature remains neutral with regard to jurisdictional claims in published maps and institutional affiliations.
Ready to submit your research? Choose BMC and benefit from:

- fast, convenient online submission

- thorough peer review by experienced researchers in your field

- rapid publication on acceptance

- support for research data, including large and complex data types

- gold Open Access which fosters wider collaboration and increased citations

- maximum visibility for your research: over 100M website views per year

At $B M C$, research is always in progress.

Learn more biomedcentral.com/submissions 